\title{
The violence of time: a game between memories in Endgame
}

\section{A violência do tempo: um jogo entre memórias em Fim de partida}

\author{
Bárbara Bravo Pires Ferreira ${ }^{1}$
}

\begin{abstract}
In his play Endgame, Samuel Beckett explores individuals divided between the simplicity and the complexity of mind and body. Therefore, considering Ricoeur's concepts of memory and body $(1968,2007)$, this article aims to analyze the knowledge from the self and the other in the play and how dependent they are on each other and their memories.
\end{abstract}

Keywords: Beckett. Memory. Theater.

Resumo: Samuel Beckett apresenta na peça Fim de Partida sujeitos envoltos na ambiguidade entre a simplicidade e a complexidade do corpo e da mente. Dessa forma, considerando os conceitos de Ricoeur $(1968,2007)$ sobre memória e corpo, o artigo procura analisar as redes de conhecimento do eu e do outro na peça e como eles são dependentes do outro e de suas memórias.

Palavras-chave: Beckett. Memória. Teatro.

In the twentieth century, especially after World War II, a difficulty in exploring the individual as a unity and memory as a fountain of stable knowledge became obvious. "In the wake of events which even the survivors cannot survive, mankind vegetates, crawling forward on a pile of rubble, denied even the awareness of its own ruin" (ADORNO, 1969, p.

1 Mestranda em Estudos de Literatura na Universidade Federal Fluminense. 
85). In that sense, Beckett's characters usually display a sense of lacking experience in life, based on the lack of knowledge of their decay - that is clear in Waiting for Godot, with the clueless figures of Vladimir and Estragon - and it is also the case of Endgame, mainly with the characters Clov and Hamm, who do not have a complete notion of why they continue to exist.

In this play, published in 1958, the author presents characters who are locked in a game between memory and individuality, exposing an interiority as suffocating as the place where they are living. Basically, the play explores three main types of limitation: a location one, through the house; a psychological one, through the memory; and a biological one, through the body. It is in Endgame that Beckett shows us how our notions about memory as a solely individual activity are unstable. Therefore, the ruins of his characters become an important trace for his definition of modern society, to which they are connected.

Besides, theater per se seems to be the most desirable genre to define a literary function related to memory. Especially because it transcends writing and reading, by expanding itself through the trio: stage, audience, and character(s). Therefore, it is not by chance that Beckett uses theater as a way to expose the human condition as unstable, because "[i] $\mathrm{f}$ the consciousness of the human condition, because of its own dismay, is profoundly tragic, its illustration in the theater seems meaningless, as a grotesque farce"2 (BERRETTINI, 1977, p. 16, our translation). ${ }^{3}$

There is, in Endgame, the exploration of dependency situation, in which the characters do not seem able to exist alone, but also of the idea of solitude, given that they present, at the same time, a refusal of the few possibilities of exploring the memory of the other, and a threatening

2 “[s]e a conscientização da condição humana, por sua total desesperança, é profundamente trágica, já a sua ilustração no teatro aparece desprovida de sentido, tal uma grotesca farsa" (BERRETTINI, 1977, p. 16).

3 All translations were done by the author of this text. The original quotations are in the footnote in order to help with its fluidity. 
through the idea of leaving. So, both of these tendencies are constantly present in the characters' speech, as in the following passage: "Clov: You don't believe me? You think I'm inventing? Pause. Hamm: It's the end, Clov, we've come to the end. I don't need you anymore. Pause. Clov: Lucky for you. [...] Clov: I'll leave you" (BECKETT, 1958, p. 50). This notion of abandonment is intensified as the play develops, until the end, in which there is no climax, given Clov's final stabilization and immovability.

In addition, we are shown an interiorized limitation manifested in the (un)defined setting of the play, that of what it seems to be a house, with as minimal components as possible to define it: "Bare interior. [...] two small windows, curtains drawn. [...] Front right, a door. [...] an armchair [...]" (BECKETT, 1958, p. II). The house also has its common components described, such as a kitchen, and a bed, which point to a family relationship. However, the signification of the house is expanded through the notion of emptiness, by which Hamm appears to be highly affected, given that he understands the house not only as part of a ruin that shows how hollow their place is, as a consequence of the wall's old composition, but also considers it to be hell (although he believes that there is another hell beyond the house): "Hamm: [...] Old wall! (Pause) Beyond is the . . other hell. (Pause. Violently.) [...] Do you hear? (He strikes the wall with his knuckles.) Do you hear? Hollow bricks! (He strikes again.) All that's hollow!" (BECKETT, 1958, p. 23). The violence inflicted to the wall is a way to emphasize how the house, with its limitation and emptiness, can hurt him, evidencing the way that the house is described as a memory of his own ruin and misery.

Another moment that explores the connection between the house and family relationships - and how strongly related they are - is when Clov denies his capacity to remember both his arrival and his father (his origins). At this point, Hamm is able to demonstrate his power over him, given his competence to have a position and a history: 
Hamm: Do you remember when you came here? Clov: No. Too small, you told me. Hamm: Do you remember your father? Clov: (wearily). Same answer. (Pause.) You've asked me these questions millions of times. Hamm: I love the old questions. (With fervour.) Ah the old questions, the old answers, there's nothing like them! (Pause.) It was that I was a father to you. Clov: Yes. (He looks at Hamm fixedly.) You were that to me. Hamm: My house a home for you. Clov: Yes (He looks about him.) This was that for me. Hamm: (proudly). But for me (gesture towards himself) no father. But for Hamm (gesture towards surroundings) no home (BECKETT, 1958, p. 29).

As a result, Hamm's character establishes his superiority over Clov's by positioning himself as memory's holder. This aspect can be considered in connection with the notion of a divine image of him as the Holy Father and the house as God's house. In this way, Hamm strips Nagg, who later affirms that he is his father, of a possible power over him by assuming, proudly, the condition of being an orphan and not having a home. In addition, whilst expressing his feelings about the house, he stresses the different meanings between the words house and home, at the most relevant moment of their use, which intensifies the game by putting himself as the one responsible for Clov, while he affirms his own lack of belonging. And, beyond this understanding, there is another one at which Hamm comes to: "Outside of here it's death" (BECKETT, 1958, p. 15). In this case, more than death's existence outside that space, there is an understanding on his part that the possibility of life is restricted to the place they are located. Being outside is being dead.

So we have in the play four characters establishing human plurality exactly through their faults, flaws, and deficiencies, in their bodies and minds. And if there are flaws in communication, we tend to consider that there are also flaws in the constitution of their memories: "The coming of a remembrance is an event. Forgetfulness is not an event, something 
that occurs or that makes itself occur"4 (RICOEUR, 2007, p. 508, our translation). The only occurrences in the play are related to the coming of remembrances, so the question, in this case, is whether this functions as the coming of remembrance or as the creation of remembrance. Because, if remembrance comes, it must come from somewhere in the past, while the creation of remembrance comes from the part of a forgotten event that takes the present as an opportunity to configure the future:

Crucially, the various stories are never really finished - and they are told not only to give the teller a belief that he or she does in fact have a past but, more importantly, to convince a listener that a past, or at least "their" past, exists. Failure is the inevitable outcome - even the punch-lines of their jokes fail to be properly understood. The reason is that none of these would-be autobiographers can believe in their own tales or even invent plausible accounts. Hamm may redefine his story as "my chronicle", that is to say, as a factual account; however, like everyone else, he is striving not to remember his past but to construct it (WORTON, 1994, p. 99).

In face of the opportunity to create a remembrance, much more than who forgot and how it was forgotten, what seems to be important to the reader/audience of the play and also to Hamm is what was forgotten, because he makes use of a memory of the past to define himself in the present time: happy then, not so happy now.

Hamm: Then he's living. (Pause.) Did you ever have an instant of happiness? Clov: Not to my knowledge. Hamm: [...] Do you remember, in the beginning, when you took me for a turn? You used to hold the chair too high. At every step you nearly tipped me out. (With senile quaver.) Ah great fun, we had, the

4 "A vinda de uma lembrança é um acontecimento. O esquecimento não é um acontecimento, algo que ocorre ou que se faz ocorrer" (RICOEUR, 2007, p. 508). 
two of us, great fun! (Gloomily.) And then we got in the way of it (BECKETT, 1958, p. 42).

In this way, the relationship between Clov and Hamm seems to be built in the difficulty to access the idea of collective memory. They create an impression of being together for a long period, sharing experiences and memories, but the problem is that Hamm presents a past that does not seem to involve Clov's memories, for he does not confirm Hamm's versions of the past. Moreover, we are able to notice a tendency to create a narrative that extends itself as a way to manipulate his own history, his own past that is forgotten or needs to be forgotten. Furhtermore, the traces of Hamm's lack of memory are exposed by the word's choice - senile - which is associated with an illusion of a past that did not happen, and which functions a sign of his advanced age.

In modern history, narrative manipulation occurs in different ways. In this case, it is taken to its extreme, especially if we consider that is does not come from the outside, as a characteristic way to control one's image from the other. It is much more than an individual's tendency to create a narrative based on the possibilities of existence inside a safe space, a controllable one; it is part of a manipulation of time as an inscription of the past by maybe choosing what Hamm wants to forget:

Clov: What is there to keep me here? Hamm: The dialogue. (Pause.) I've got on with my story. (Pause.) I've got on with it well. (Pause. Irritably.) Ask me where I've got to. Clov: Oh, by the way, your story? Hamm: (surprised.) What story? Clov: The one you've been telling yourself all your ... days. Hamm: Ah you mean my chronicle? Clov: That's the one. (Pause). Hamm: (angrily.) Keep going, can't you, you keep going! Clov: You've got on with it, I hope (BECKETT, 1958, p. 40).

In the lack of a complex reconfiguration of the world he is part 
of, Hamm shows how necessary it is to build his identity, even if it comes from his own narrative. In this sense, memory is part of that discursive creation coming from the character, expressed in a way that outlines his insufficiencies of interpretation, from the impossibility of an assertive or even confirmative contact with the other.

Given that the knowledge of oneself is an interpretation, and considering that this interpretation is expressed in a narrative way, the narrative act is a privileged form of a subject's constitution of identity, an identity created not only by a historical narrative but also by fiction, since, as we have seen, the later also acts towards the world's reconfiguration ${ }^{5}$ (BONA, 2012, p. 188, our translation).

This is the order that Hamm insists to affirm, which remains at a different level from Clov's perception of order, which could only be realized in total immobility and complete silence: "It's my dream. A world where all would be silent and still and each thing in its last place, under the last dust" (BECKETT, 1958, p. 39).

It is important to consider that there is not, at any point in the play, a mention of the word memory. Memory does not appear either in the text, as a linguistic device, or as an act capable of realization. However, the word remembers and its variations occur: "Nagg: Do you remember

Nell: No. Nagg: When we crashed on our tandem and lost our shanks. (They laugh heartily.) Nell: It was in the Ardennes. (They laugh less heartily.) Nagg: On the road to Sedan. (They laugh still less heartily.) Are you cold?" (BECKETT, 1958, p. 18-19). The question, in this case, is how the individual articulates truth with memory through his life's narrative, for "[a] subject's life story is refigured by the set of real or fictional stories that

\footnotetext{
5 "Sendo o conhecimento de si próprio uma interpretação e sendo a interpretação expressa de modo narrativo, a narratividade é a forma privilegiada de constituição da identidade de um sujeito, identidade essa que se faz tanto pela narrativa histórica como pela de ficção, uma vez que, como vimos, essa última também atua no sentido da refiguração do mundo" (BONA, 2012, p. 188).
} 
this person tells about himself throughout his life. And these notions apply both to the identity of an individual and that of a community"6 (BONA, 2012 , p. 187, our translation). The characters' lives in the present are a reflection of what and how they lived in their past. Hamm, as the figure whose power is shown through his memory and his ability to remember, is the one who is more able to explore his individuality. However, given the instability to build an identity of the group of people accompanying him, his notions of past are affected by stories which are not exactly involving him as the main figure: "Hamm: I once knew a mad man who thought the end of the world had come. He was a painter-and engraver. I had a great fondness for him [...] Clov: A madman? When was that? Hamm: Oh way back, way back, you weren't in the land of the living" (BECKETT, 1958, p. 32). For Clov, those memories are not a part of him, because he was not alive or not living in his land. They belong in the past because Hamm can do nothing about them now, if he believes, as he had great fondness for him, that what he is living is the end of the world.

In this case, it does not matter if those stories are true or part of a work of fiction, their function is to fill out an individual that seems empty in his existence and sees himself insufficiently portrayed in that space and in that narrative:

This would seem to imply that the characters look forward to the future, yet if there is no past, there can be neither present nor future. So in order to be able to project onto an unlocatable - and perhaps nonexistent - future, the characters need to invent a past for themselves. And this they do by inventing stories (WORTON, 1994, p. 99).

Moreover, as Hamm's identity is developed through his speech,

\footnotetext{
6 "A história de vida de um sujeito é refigurada pelo conjunto das histórias verdadeiras ou fictícias que esse sujeito conta de si mesmo ao longo da vida. E essas concepções aplicam-se tanto à identidade de um indivíduo como à de uma comunidade" (BONA, 2012, p. 187).
} 
the community's identity (all the other characters in that hostile room) is also being developed, given that, at a certain level, these characters are considered as a community which share experiences: "Clov: (harshly.) When old Mother Pegg asked you for oil for her lamp and you told her to get out to hell, you knew what was happening then, no? (Pause.) You know what she died of, Mother Pegg? Of darkness" (BECKETT, 1958, p. 48).

Furthermore, based on the assumption that: "the unity of the world and the unity of man are too close and interpenetrated: close as a horizon that it is never reached, as an image seen through an infrangible glass window"7 (RICOEUR, 1968, p. 200, our translation), we can understand how it is precisely in this unreachable horizon that Beckett constitutes his text, so that unity becomes an impossibility. That is why the inquiry over nature's existence is added as an opening for the inconstant notion of lack of contact and even as a realization of the mutual incursion from both units - world and men: "Hamm: Nature has forgotten us. Clov: There is no more nature. Hamm: No more nature! You exaggerate. Clov: In the vicinity. Hamm: But we breathe, we change! We lose our hair, our teeth! Our bloom! Our ideals! Clov: Then she hasn't forgotten us" (BECKETT, 1958 , p. 16). What they are calling nature, in this case, is intrinsically related to the passage of time, which seems to be the main feature left from its presence; even nature remains almost as an absence. Not realizing nature's existence does not mean it is less present. At the same time, they are including themselves in an existential incursion, as changeable and functional humans, so the idea of a presence in that space seems crucial to understand their existence as it is. Meanwhile, it is the memory's lapse that becomes part of the game in Endgame. They deny first, so that they can follow this denial with an affirmative. It is a contradictory flow that only

\footnotetext{
7 "A unidade do mundo e a unidade do homem estão por demais próximas e interpenetradas: próximas como um horizonte que jamais se atinge, como uma figura vista através de uma vidraça infrangível" (RICOEUR, 1968, p. 200).
} 
memory can offer, especially through speech, so Hamm, even blind and paralyzed, has the power to manipulate Clov. "Therefore, we have access to events reconstructed for us by others. So, it is by their place in a group that others are defined"8 (RICOEUR, 2007, p. 131, our translation). In that sense:

Of course, my place is there, where my body is. But locating oneself and dislocating oneself are primary activities that turn a place into something to be searched. It would be frightening to find none. We ourselves would be devastated. The unsettling strangeness - Unheimlichkeit - related to the feeling of not being in one's place even in one's own house haunts us, and that would be the domain of emptiness ${ }^{9}$ (RICOEUR, 2007, p. 157-158, our translation).

It is in this domain of emptiness that the characters of Engdame find themselves. The idea of a place, alongside the idea of a body are flaws to the extent that the character's bodies are not whole, they are not completely functioning in their biological competences. For this reason, Clov's relationship with Hamm and even his attempts to leave him are pertinent to the idea that he does not feel in his own place in that space:

Clov: (as before). How easy it is. They said to me, That's friendship, yes yes, no question, you've found it. They said to me, Here's the place, stop, raise your head and look at all that beauty. That order! They said to me, come now, you're not a brute beast, think upon these things and you'll see how all becomes clear. And simple! They said to me, What skilled attention they get, all these dying of their wounds (BECKETT, 1958, p. 51).

"I understand death as an inevitable destiny of the body-object; 
I understand it by the biology confirmed through everyday experience"10 (RICOEUR, 2007, p. 369, our translation). We have, in this case, the formation of what we consider men from their images as body-objects. Based on those experiences, they are repressed from their bodies' conditions as limitations arrive, also as the idea of an inevitable destiny, while they depend on each other in waiting for their deaths: "Hamm: (...) Why do you stay with me? Clov: Why do you keep me? Hamm: There's no one else. Clov: There's nowhere else." (BECKETT, 1958, p. 14). Apart from that, we understand that "[...] the four characters of Endgame - Hamm, blind and paralytic; Nagg and Nell, his parents, with no legs and always retracted in garbage bins; Clov, unable to sit - are remnants of human beings"11 (BERRETTINI, 1977, p. 14, our translation). Likewise, they are also leftovers in the condition of their memory, serving as evidence of human beings incompleteness.

Similarly, "[i]n a different language, that of Hannah Arendt, solitude is the counterpart of the fact of human diversity. Solitude remains fundamentally an interruption of mutual communication, and it shows its intermittencies"12 (ARENDT apud RICOEUR, 2007, p. 470, our translation). Arendt's notion of solitude can be seen in Endgame as we aim to understand how their solitude is exposed, not only by the lack of human contact with the outside world but also by how the conversations between the characters are continually expressed by a discontinuous feeling, as fragments in which there is not a satisfactory response to their questions, since there is not a satisfactory existence to their beings.

Moreover, even the notion of time defined by days and months

\footnotetext{
10 "Aprendo a morte como destino inelutável do corpo-objeto; aprendo-a pela biologia confirmada pela experiência cotidiana” (RICOEUR, 2007, p. 369).

11 “[...]as quatro personagens de Fim de Jogo - Hamm, cego e paralítico; Nagg e Nell, seus pais, sem pernas e sempre recolhidos em latas de lixo; Clov, impossibilitado de sentar-se -são antes restos de criaturas humanas" (BERRETTINI, 1977, p.14).

12 "[n]uma outra linguagem, a de Hannah Arendt, a solidão é a contrapartida do fato da pluralidade humana. A solidão permanece fundamentalmente como uma interrupção da comunicação recíproca e mostra suas intermitências" (ARENDT apud RICOEUR, 2007, p. 470).
} 
is questioned by them, as another mechanism to mark the uncertainty of their lives, when, for instance, Hamm asks: "What month are we? [...]" (BECKETT, 1958, p. 43), or in the following passage:

Hamm: [...] Is it light? Clov: It isn't dark. Hamm: (angrily.) I'm asking you is it light. Clov: Yes. (Pause.) Hamm: The curtain isn't closed? Clov: No. Hamm: What window is it? Clov: The earth. Hamm: I knew it! (Angrily.) But there's not light there! The other! (Clov pushes chair towards window left.) The earth! (Clov stops the chair under window left. Hamm tilts back his head.) That's what I call light! (Pause.) Feels like a ray of sunshine. (Pause.) No? Clov: No (BECKETT, p. 42).

Knowing what day it is and what its existence means to them is a challenge, given the continuum they are in, where every question seems to be made a thousand times, and every movement repeated to exhaustion:

Clov: I oiled them yesterday. Hamm: Yesterday! What does that mean? Yesterday! Clov: (violently.) That means that bloody awful day, long ago, before this bloody awful day. I use the words you taught me. If they don't mean anything anymore, teach me others. Or let me be silent" (BECKETT, 1958, p. 32).

Likewise, it is interesting to notice a certain recurrence of the word time, appearing as a mark of the question that will return throughout the whole play (with its variations), which is: "Is it not time for my painkiller?" (BECKETT, 1958, p. 46). The expression will function as a key to represent Hamm's existence as painful, until the pain-killer's own existence is denied, as if it never existed, as if it was a lie that would never work.

In summary, in Endgame Samuel Beckett presents characters that are constantly fighting for an answer, fighting for a reply, although they are 
mainly committed to their own visions of life. Hamm, Nell, Nagg and Clov are all trapped in their house and in their past, with no chance of change. Memory for them is malleable and it bents according to their will, even though they are aware that they are stuck with others who have a different understanding of their experiences of past, present and, eventually, future. Consequently, their ideas of time are related to what can be extracted or created from memory, as the source of drive to persist, as a meaning to their lives.

\section{References}

ADORNO, Theodor. Towards an Understading of Endgame. In: CHEVIGNY, Bell. (ed). Twentieth Century's Interpretations of Endgame: A Collection of Critical Essays. New Jersey: Prentice Hall, 1969.

BECKETT, Samuel. Endgame. London: Faber and Faber, 1958.

BERRETTINI, Célia. A linguagem de Beckett. São Paulo: Perspectiva, 1977.

BONA, Aldo Nelson. História, verdade e ética: Paul Ricoeur e a epistemologia da história. Guarapuava: Unicentro, 2012.

RICOEUR, Paul. A memória, a história, o esquecimento. Tradução Alain François [et al.]. Campinas: Editora da Unicamp, 2007.

. História e Verdade. Tradução F.A. Ribeiro. Rio de Janeiro: Companhia Editora Forense, 1968.

WORTON, Michael. Waiting for Godot and Endgame: Theatre as text. In: PILLING, John. (ed.). The Cambridge Companion to Beckett. Cambridge: Cambridge University Press, 1994.

Recebido em: $31 / 10 / 2019$

Aprovado em: 22/05/2020 